\title{
PEMBERDAYAAN IBU-IBU RUMAH TANGGA MELALUI PELATIHAN PEMBUKUAN SESUAI PSAK ETAP DAN MANAJEMEN USAHA UNTUK MENINGKATKAN PENDAPATAN EKONOMI KELUARGA DI KELURAHAN METESEH KECAMATAN TEMBALANG KOTA SEMARANG
}

\author{
Windasari Rachmawati', Abdul Manan², Abdul Karim ${ }^{3}$ \\ Fakultas Ekonomi, Universitas Semarang \\ Jl. Soekarno Hatta, Tlogosari Kulon, Kec. Pedurungan, Kota Semarang, Jawa Tengah \\ Email korespondensi : windasarirachmawati@usm.ac.id
}

\begin{abstract}
ABSTRAK
Kelurahan Meteseh terletak di Kecamatan Tembalang merupakan salah satu kecamatan di wilayah Kota Semarang, Propinsi Jawa Tengah. Di Kelurahan Meteseh sekarang ini sedang diberdayakan ibu ibu dalam merintis usaha aneka olahan pangan, biasanya pembuatan otak otak bandeng presto, bandeng presto, kue bolu karamel, onde - onde dari tepung mocaf. Tujuan dari dilaksanakan PKM ini adalah dapat memberikan memberikan pelatihan bagaimana proses pembukuan dan manajemen pemasaran bagi usahanya. Target yang ingin dicapai adalah masyarakat menjadi kreatif dan bisa membuat laporan keuangan dan bagaimana melakukan pemasaran dari kretifitas yang dihasilkan, untuk dijadikan salah satu ide untuk dijadikan peluang untuk berwirausaha seehingga dapat meningkatkan pendapatan keluarga dan mampu menganalisis kelayakan berwirausaha dalam menghasilkan dan mengolah aneka jajanan pasar. Metode pelaksanaan kegiatan PKM ini adalah pemberian pelatihan pembukuan dan manajemen pemasaran. Hasil dan Luaran yang ditargetkan oleh pengabdian adalah dengan adanya pelatihan membuat pembukuan dan pemasaran produk maka masyarakat yang mengikuti pelatihan akan termotivasi untuk berwirausaha terutama membuat hasil olahan aneka jajanan pasar yang lebih bervariatif sehingga dapat meningkatkan pemahaman dan pengetahuan mengenai pembukuan dan manajemen usaha dan dapat meningkatkan perekonomian keluarga.
\end{abstract}

Kata Kunci : Pemberdayaan, Motivasi , Pelatihan

\begin{abstract}
Meteseh Village is located in Tembalang District, which is one of the sub-districts in Semarang City, Central Java Province. In the Kelurahan Meteseh, women are currently being empowered in pioneering various food processing businesses, usually making presto milkfish brains, presto milkfish, caramel sponge cake, dumplings from mocaf flour. The purpose of implementing Community Service is to be able to provide training on how to process bookkeeping and marketing management for their business. The target to be achieved is for the community to be creative and be able to make financial reports and how to do marketing of the creativity produced, to be used as an idea to be used as an opportunity for entrepreneurship so that it can increase family income and be able to analyze the feasibility of entrepreneurship in producing and processing various market snacks. The method of implementing community service activities is the provision of training in bookkeeping and marketing management. The results and outputs targeted by the service are with training in bookkeeping and product marketing, so people who take part in the training will be motivated to become entrepreneurs, especially making more varied processed market snacks so they can improve understanding and knowledge of bookkeeping and business management and can improve the family economy.
\end{abstract}

Keywords: Empowerment, Motivation, Training 


\section{PENDAHULUAN}

Kelurahan Meteseh terletak di Kecamatan Tembalang Kota Semarang, Propinsi Jawa Tengah. Luas Wilayah Kelurahan Meteseh 855,838 Ha. Dengan batas-batas kelurahan sebelah utara berbatasan dengan Kelurahan mangunharjo, sebelah selatan berbatasan dengan kelurahan jabungan kecamatan banyumanik, sebelah barat berbatasan dengan kelurahan bulusan, dan sebelah timur berbatasan dengan Kelurahan Rowosari.

Visi dan Misi Kelurahan Meteseh. VISI "Terwujudnya masyarakat sehat yang memiliki kemampuan cipta,rasa,dan karya yang tinggi dengan berkarakter, demokratis, berbudaya, partisipatif, mandiri, kreatif, menguasai ilmu pengetahuan dan teknologi serta sejahtera. ". Adapun MISI yaitu: 1) Mewujudkan sumber daya manusia yang berpengetahuan, berkemampuan,dan berkepribadian serta religius. 2) Mewujudkan kelurahan yang sehat. 3) Mewujudkan peningkatan pelayanan publik. 4) Mewujudkan keberdayaan masyarakat dalam pembangunan. 5) Mewujudkan taraf hidup masyarakat.

Berdasarkan data monografi yang didapatkan bahwa pada Kelurahan Meteseh diketahui dominasi penduduknya bekerja lain - lain. Menurut mata pencahariannya ternyata sebagian besar penduduknya menjadi buruh industri dan buruh bangunan. Sementara itu industri kecil kurang berkembang, dimana jumlah pengrajinnya tercatat sebesar 58 orang. Hal ini dapat dilihat dari data pada table 1 tentang Jumlah Penduduk Menurut Mata Pencaharian.

Tabel 1. Jumlah Penduduk Menurut Mata Pencaharian (Umur 10 Th Ke atas) Kelurahan Meteseh, Kecamatan Tembalang, Kota Semarang, 2019

\begin{tabular}{|l|c|}
\hline Mata Pencaharian & Jumlah \\
\hline Petani : & orang \\
- Pemilik tanah & orang \\
- Penggarap tanah & orang \\
- Buruh tani Pengusaha sedang/besar & 18 orang \\
Pengrajin/Industri Kecil & 58 orang \\
Buruh Industri & 1148 orang \\
Buruh Bangunan & 1569 orang \\
Pedagang & 350 orang \\
Pengangkutan & 10 orang \\
Pegawai Negeri Sipil ABRI & 982 orang \\
Pensiunan Peternak & 325 orang \\
Lain-lain & 335 orang \\
& 15 orang \\
& 2516 orang \\
\hline Jumlah & 7326 orang \\
\hline
\end{tabular}

Sumber : Monografi Kelurahan Meteseh, 2019 
Dari table 1. di atas dapat diketahui penduduk dengan mata pencaharian buruh menempati jumlah terbanyak. Sedangkan Pengusaha dan pengrajin jumlahnya sedikit sekali hal ini bertolak belakang dengan visi dan misi Kelurahan Meteseh. Pada dasarnya dari data diatas menunjukkan bahwa kegiatan Usaha Mikro Kecil dan Mengengah (UMKM) masih belum berkembang di Kelurahan ini. Masyarakat kurang atau belum kreatif dalam bidang ekonomi. Padahal dilihat dari jumlah penduduknya yang sangat besar, hal ini merupakan potensi bagi wilayah ini untuk bisa berkembang kegiatan UMKM. Oleh karena itu sangatlah penting untuk menggerakkan masyarakat agar mau berwirausaha atau menjadi pelaku UMKM.

Berdasarkan Monografi kelurahan Meteseh, dapat dilihat jumlah pencari kerja yang tercatat sebanyak 379 orang, yang terdiri dari 131 orang laki- laki dan 248 perempuan. Hal ini menunjukkan bahwa ternyata banyak penduduk Kelurahan Meteseh yang masih belum bekerja. Sebenarnya bekerja tidak harus menjadi pegawai negeri atau karyawan swasta. Apabila mereka mempunyai bekal pengetahuan dan keterampilan maka mereka bisa menjadi wirausahawan dan kemungkinan bisa juga menciptakan peluang kerja bagi orang lain. Untuk itu perlu dilakukan pembekalan bagi masyarakat kelurahan Meteseh tentang kewirausahaan agar mereka terbuka wawasannya, sehingga timbul keinginannya untuk berwirausaha.

Tabel 2. Jumlah Pencari Kerja

\begin{tabular}{|c|c|}
\hline Pencari Kerja & Jumlah \\
\hline Laki-laki & 131 orang \\
\hline Perempuan & 248 orang \\
\hline Jumlah & 379 orang \\
\hline
\end{tabular}

Sumber: Monografi Kelurahan Meteseh, 2019

Disamping banyak jumlah pencari kerja, di kelurahan Meteseh juga terdapat banyak ibu-ibu yang tidak bekerja yang memiliki banyak waktu luang. Ibu- ibu rumah tangga adalah kelompok yang memungkinkan untuk diberdayakan dalam kegiatan UMKM. Apabila ibu-ibu rumah tangga ini diberdayakan dengan baik, maka diharapkan ibu-ibu rumah tangga ini mampu menghasilkan suatu produk yang memiliki nilai ekonomis sehingga akan mampu meningkatkan ekonomi keluarganya. Untuk masyarakat terutama kelas menengah dan bawah, tugas seorang ibu selain menjadi ibu dan isteri, tetapi juga bertugas membantu ekonomi keluarga. Keberadaan ibu-ibu ini merupakan salah satu potensi untuk bisa mengembangkan UMKM di kelurahan ini. Apalagi tingkat pendidikan penduduk kelurahan Meteseh cukup tinggi, yang berarti mereka cukup mampu untuk mengembangkan diri. Ibu-ibu rumah tangga ini bisa memanfaatkan waktu luangnya dengan berwirausaha. Dengan adanya kegiatan wirausaha diharapkan akan bisa membantu masyarakat setempat untuk meningkatkan pendapatan keluarga. 
Menurut Soegoto (2009) bahwa kewirausahaan atau entrepreneurship adalah usaha kreatif yang dibangun berdasarkan inovasi untuk menghasilkan sesuatu yang baru, memiliki nilai tambah, memberi manfaat, menciptakan lapangan kerja dan hasilnya berguna bagi orang lain.

Berdasarkan latar belakang di atas, maka tim pengabdian kali ini berupaya untuk mendorong ibu-ibu rumah tangga yang memiliki banyak waktu yang tidak produktif di Kelurahan Meteseh menjadi kreatif untuk membuat produk yang bernilai ekonomis. Sehingga diharapkan suatu saat nanti masyarakat bisa menjadi wirausahawan yang berhasil. Hal ini merupakan upaya untuk mewujudkan visi dan misi kelurahan Meteseh, yaitu "Semarang Kota Perdagangan dan Jasa yang Hebat Menuju Masyarakat Semakin Sejahtera".

Bagi dirinya sendiri seorang wirausaha berperan dalam mengurangi tingkat kebergantungan terhadap orang lain, meningkatkan kepercayaan diri, serta meningkatkan daya beli pelakunya. Sementara itu bagi masyarakat seorang wirausaha berperan dalam menyediakan lapangan kerja bagi para pencari kerja. Dengan terserapnya tenaga kerja oleh kesempatan kerja yang disediakan seorang wirausaha, tingkat pengangguran akan menjadi berkurang. Menurunnya tingkat pengangguran berdampak terhadap naiknya pendapatan perkapita dan daya beli masyarakat, serta tumbuhnya perekonomian secara nasional. Selain itu, berdampak pula terhadap menurunnya tingkat kriminalitas yang biasanya ditimbulkan oleh karena tingginya pengangguran.

\section{Permasalahan Mitra}

Berdasarkan keterangan di atas bahwa masalah yang ada dikelurahan Meteseh adalah masih banyak ibu ibu rumah tangga yang bekerja dalam ekonomi kreatif dengan membuat aneka jajanan ada yang berbahan tepung terigu atau tepung mocaf, contohnya bolu karamel,bolu kukus, onde onde tepung mocaf. Ada juga ibu rumah tangga yang memiliki umkm otak otak bandeng presto dan aneka olahan bandeng. Pada pengabdian masyarakat kali ini diangkat suatu perumusan masalah yaitu bagaimana memberdayakan ibu-ibu rumah tangga untuk meningkatkan pendapatan keluarga melalui pelatihan membuat pembukuan sesuai psak ETAP dan manajemen pemasaran bagi masyarakat di Kelurahan Meteseh, Kecamatan Tembalang Kota Semarang.

\section{Tujuan Pengabdian}

Dengan adanya pelatihan yang diberikan kepada Masyarakat ini bertujuan :

1. Diharapkan masyarakat Kelurahan Meteseh setelah diberikan pelatihan mengenai pembuatan pembukuan dan manajemen usaha timbullah keinginan untuk berwirausah dan mampu mengembangkan Usaha industri kretaif masyarakat melalui aneka olahan pangan.

2. Diharapkan Masyarakat yang mengikuti pelatihan ini dapat membuat laporan keuangan dan memasarkan hasil produknya aneka olahan ikan bandeng dan jajan pasar yang menjadi produk andalan dan dapat mengembangkan berbagai macam variasi makanan berbahan ikan dan tepung mocaf. 
3. Diharapkan setelah mengikuti pelatihan dan masyarakat mulai berwirauwaha dalam membuat Produk dari ikan dan tepung terigu atau tepung mocaf maka akan meningkatkan perekonomian keluarga.

\section{Solusi}

Berdasarkan permasalahan yang telah diuraikan pada bab sebelumnya, yaitu masih banyak ibu-ibu rumah tangga yang tidak bekerja dan kegiatan UMKM belum berkembang, maka solusi yang diambil adalah memberikan pelatihan membuat produk yang bernilai ekonomis untuk meningkatkan ekonomi keluarga bagi masyarakat di Kelurahan meteseh, Kecamatan Tembalang, Kota Semarang. Pelatihan dalam pengabdian masyarakat kali ini adalah membuat pelatihan pembukuan dan manajemen usaha. Menurut UU Nomor 28 Tahun 2007 Pasal 28, pembukuan adalah suatu proses pencatatan yang dilakukan secara teratur untuk mengumpulkan data dan informasi keuangan yang meliputi harta, kewajiban, modal, penghasilan, dan biaya, serta jumlah harga perolehan dan penyerahan barang atau jasa, yang ditutup dengan menyusun laporan keuangan berupa neraca, dan laporan laba rugi untuk periode tahun pajak tersebut.

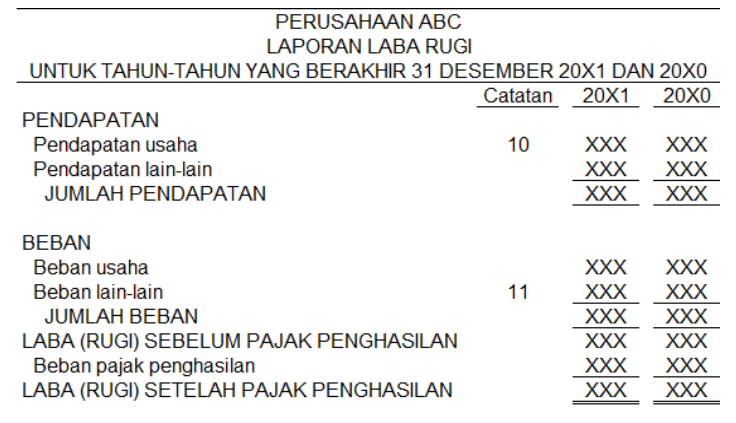

\section{Gambar 1. Contoh laporan Laba Rugi sesuai PSAK ETAP}

Manajemen usaha atau business management adalah proses perencanaan, pengorganisasian, memimpin, staff dan mengendalikan kegiatan berbagai sumber daya dalam organisasi melalui usaha manusia sistemik, terkoordinasi dan kooperatif untuk mencapai tujuan organisasi.

\section{METODE PELAKSANAAN}

1. Metode pelaksanaan pengabdian pada masyarakat ini adalah Pelatihan. Dalam hal ini memberikan pelatihan pembukuan dan manajemen usaha.

2. Tahap-tahap pengabdian kepada masayarakat:

a. Tahap Persiapan

Tahap persiapan merupakan tahap awal sebelum pelaksanaan kegiatan.

Dalam tahap ini ada beberapa hal yang dilakukan yaitu:

1). Pra Survei : Identifikasi Permasalahan dan Kebutuhan Mitra 
2). Pembuatan Proposal : Pembuatan proposalyang menawarkan solusi untuk permasalahan dan kebutuhan mitra

3). Persiapan bahan pelatihan : Yaitu mempersiapkan bahan-bahan yang akan dipakai untukpelatihan

b. Tahap Pelaksanaan

Pada tahap pelaksanan dilakukan pelatihan kepada ibu-ibu. Kegiatan dilaksanakan di balai Kelurahan Sambiroto, Kecamatan Tembalang, Kota Semarang. Adapun pelatihan yang diberikan adalah membuat pembukuan dan manajemen usaha.

c. Tahap Evaluasi

Evaluasi dilakukan dengan kuesener untuk mengetahui tingkat pemahaman peserta pengabdian terhadap pelatihan yang diberikan.

d. Tahap Pembuatan Laporan

Pada tahap akhir dibuat laporan kegiatan Pengabdian Kepada Masyarakat tentang pemberdayaan ibu-ibu rumahtangga untuk meningkatkan ekonomi keluarga.

3. Evaluasi Pelaksanaan Program

Tabel 3. Evaluasi Program

\begin{tabular}{|l|l|l|l|l|}
\hline No & Program & Indikator & Kriteria & Instrumen \\
\hline 1 & $\begin{array}{l}\text { Aspek } \\
\text { pemberdayaan } \\
\text { masyarakat }\end{array}$ & $\begin{array}{l}\text { Tingkat } \\
\text { Kreativitas dan }\end{array}$ & $\begin{array}{l}\text { Terciptanya } \\
\text { kreativitas baru dan }\end{array}$ & $\begin{array}{l}\text { Kuesioner dan hasil } \\
\text { produksi }\end{array}$ \\
$\begin{array}{l}\text { Tingkat } \\
\text { ketrampilan }\end{array}$ & $\begin{array}{l}\text { Terjadi } \\
\text { peningkatan } \\
\text { ketrampilan } \\
\text { membuat produk }\end{array}$ & \\
\hline
\end{tabular}

\section{HASIL PELAKSANAAN DAN PEMBAHASAN}

Pengabdian kepada masyarakat yang telah kami lakukan mengenai pelatihan pembuatan laporan keuangan berdasarkan PSAK ETAP dan manajemen usaha pada ibuibu rumah tangga Kelurahan Meteseh Kecamatan Tembalang melalui kegiatan kelompok usaha bersama adalah sebagai berikut :

1. Sedikitnya masyarakat yang berwirausaha pada Kelurahan Meteseh. Dalam hal ini tim pengabdi mencoba berupaya untuk meningkatkan keinginan dan kesadaran akan pentingnya pembukuan serta manajemen usaha pada umkm yang berdomisili di kelurahan tersebut, dengan memberikan pelatihan mengenai membuat pembukuan laporan keuangan sesuai PSAK ETAP dan manajemen usaha, sehingga munculah keinginan untuk berwirausaha dengan lebih teliti lagi tentang pengeluaran dan pemasukan selama proses produksi, serta adanya manajemen usaha dalam bidang pemasaran dibisnisnya. 
2. Pada Saat proses praktek membuat laporan keuangan sesuai standard PSAK ETAP dan manajemen usaha para UMKM aneka olahan pangan ini sangatlah antusias sekali sehingga berjalan dengan baik, dan timbulnya motivasi untuk lebih meningkatkan ketertiban dalam proses pembukuan, sehingga diharapkan umkm nantinya bisa lebih kedepan dalam usahanya.

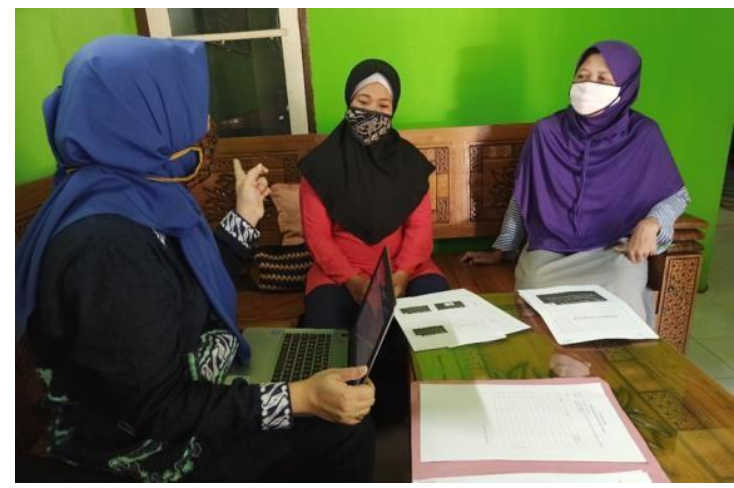

Gambar 2. Pelaksanaan pengabdian kepada masyarakat di masa pendemic dengan protokol kesehatan.

Pada pengabdian kepada masyarakat Kelurahan Meteseh Kecamatan Tembalang adalah sebagai berikut:

a. Peningkatan Keinginan kepada ibu-ibu umkm untuk berwirausaha sehingga mampu meningkatkan pendapatan.

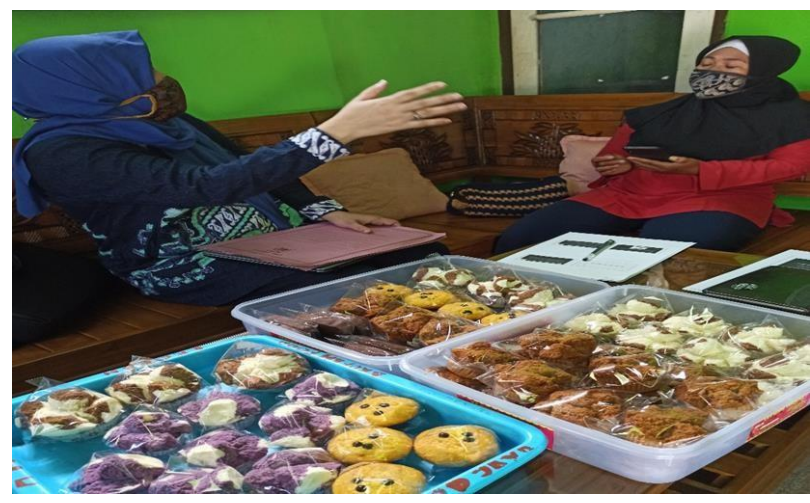

Gambar 3. Hasil olahan pangan yang dihasilkan ibu ibu rumah tangga dikelurahan Meteseh kecamatan Tembalang

b. Peningkatan kesejahtraan pada Ibu-Ibu umkm dengan berwirausaha sendiri dengan membuat pembukuan sendiri dan mengembangkan usahanya.

a. Peningkatkan pengetahuan kepada ibu - ibu UMKM olahan pangan yang menghasilkan pembukuan keuangan yang tersusun rapi.

b. Pengembangkan kreatifitas ibu - ibu umkm dalam mengolah sumber daya yang ada supaya bisa menghasilkan keuntungan. Contohnya tepung mocaf dari bahan baku singkong diolah menjadi onde - onde. 


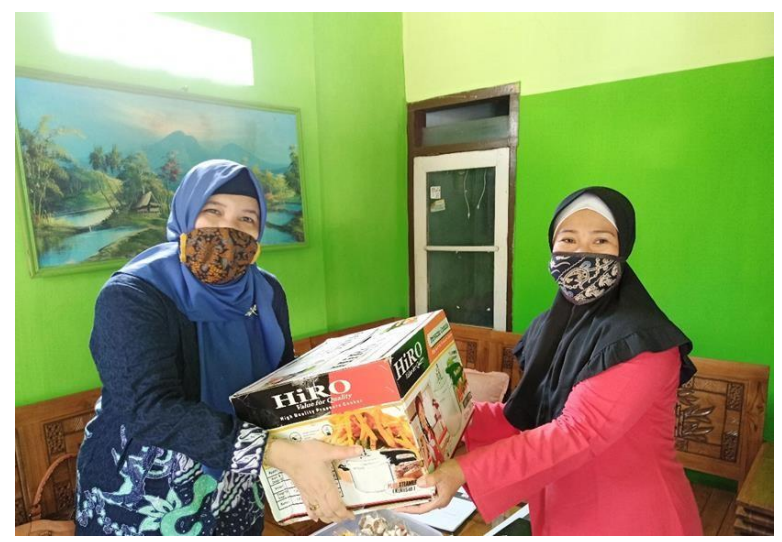

Gambar 4. Bantuan bagi pengembangan usaha ibu - ibu rumah tangga di masa pandemik

\section{KESIMPULAN DAN SARAN}

\section{Kesimpulan}

Dari hasil pelaksanaan pengabdian kepada masyarakat melalui pelatihan membuat pembukuan sesuai PSAK tetap dan manajemen usaha dapat disimpulkan sebagai berikut : 1) Ibu-ibu rumah tangga lebih mengetahui dan memahami arti pentingnya dan manfaat berwirausaha. 2) Ibu-ibu rumah tangga lebih terampil memahami proses pembuatan pembukuan. 3) Ibu-ibu rumah tangga mampu membuat pembukuan mulai laporan laba rugi, dan neraca. 4) Ibu-ibu rumah tangga masih mengharapkan kedatangan tim pengabdian untuk melatih ketrampilan lainnya untuk menambah wawasan mereka.

\section{Saran}

Untuk lebih meningkatkan penguasaan dalam berwirausaha terutama dalam pembuatan pembukuan dan manajemen usaha, ibu-ibu umkm yang belum mengikuti pelatihan diharapkan bisa lebih aktif lagi dalam menghadiri pertemuan-pertemuan yang bermanfaat dalam meningkatkan pengetahuan dan ketrampilannya. Dalam hal ini yang dibutuhkan peran serta dalam berbagai pihak bimbingan dan konseling. Kemudia, peran serta pemerintah dan pihak swasta yang selalu diharapkan untuk memberikan pelatihan pembukuan atau mengenai pemasaran lebih lanjut mengenai berwirausaha.

\section{REFERENSI}

Soegoto, Eddy Soeryanto. (2009). Enterpreneurship, Menjadi Pebisnis ulung. Kompas Gramedia . Jakarta

, (2018), Monografi Kelurahan Meteseh, Kecamatan Tembalang, Kota Semarang

https://www.jurnal.id/id/blog/2018-tips-sukses- menerapkan-manajemen-usaha-untukbisnis-kecil/

Rizki rudiantoro. (2012), "kualitas laporan keuangan UMKM serta prospek implementasi SAK ETAP”jurnal akuntansi dan keuangan Indonesia Vol.9 no.1 